\title{
Cloning of Rat Interleukin-3 Receptor $\beta$-Subunit from Cultured Microglia and Its mRNA Expression in vivo
}

\author{
Kurt Appel, ${ }^{1}$ Manuel Buttini, ${ }^{2}$ André Sauter, ${ }^{2}$ and Peter J. Gebicke-Haerter ${ }^{1}$ \\ 'Department of Psychiatry, University of Freiburg Medical School, D-79104 Freiburg, Germany and ${ }^{2}$ Preclinical \\ Research, Sandoz Ltd., CH-4002 Basle, Switzerland
}

The high-affinity receptors for interleukin-3 (IL-3), GM-CSF, and IL-5 are composed of a ligand binding $(\alpha-)$ and a transducing ( $\beta-$-) subunit. Two distinct transducing subunits (clones AIC2A and AIC2B) have been cloned from mouse, whereas in humans, only one (common) $\beta$-subunit $\left(\beta_{c}\right)$ has been found. A PCR-based cloning strategy was used to obtain a full-length cDNA sequence from rat microglia including 5'-untranslated regions. Sequence analysis revealed a number of features indicative of the presence of only one $\beta$-subunit in the rat. Most likely, the new rlL-3RB cDNA is the rat equivalent of human respective murine (AIC2B) $\beta_{c}$ subunits. Regulation of rIL-3Rß mRNA expression was investigated in cultured microglia and in vivo. Purified microglia expressed significant amounts of rIL-3R 3 mRNA. Addition of lipopolysaccharide (LPS) resulted in a marked upregulation of rIL-3R $\beta$ mRNA within approximately $4 \mathrm{hr}$. No downregulation was observed within 1 week's treatment. No rIL-3R $\beta$ mRNA was detectable in normal rat brain. However, $3 \mathrm{hr}$ after a single injection of LPS into the tail vein of a rat, a marked induction of receptor mRNA occurred in a variety of brain regions. Transcriptional rates subsided significantly after $24 \mathrm{hr}$. rIL-3RB mRNA was visualized by in situ hybridizations with cRNA antisense probes in ramified cells formerly characterized as microglial cells. rIL-3R $\beta$ mRNA was also induced in rat brain after occlusion of middle cerebral artery (MCAO). Time course of induction was slower than in lipopolysaccharide (LPS)treated animals and lasted for more than $24 \mathrm{hr}$ until a significant downregulation became apparent. In centers of infarcted areas, receptor-positive cells likely were bloodborne macrophages and microglia, whereas in areas distant from lesions, cells with morphologies typical of microglia stained positive with digoxigenin (dig)-labeled CRNA probes. It is concluded, that induction of rlL-3R $\beta$ mRNA in brain microglial cells is a very early marker of microglial activation in vivo.

[Key words: microglia, interleukin-3, receptor, fever induction, middle cerebral artery (MCAO), RT-polymerase chain reaction, $R A C E]$

\footnotetext{
Received Jan. 25, 1995; revised $\Lambda$ pril 7, 1995; accepted $\Lambda$ pril 12, 1995.

We are grateful to Prof. M. Berger, to Dr. H. W. G. M. Boddeke, and to the Deutsche Forschungsgemeinschaft (Grant Ge 486/6-2) for invaluable support of this work. The sequencing work done by Dr. G. Igloi, Biology III, University of Freiburg, is greatly acknowledged.

Correspondence should be addressed to P. J. Gebicke-Haerter, Psychiatrische Universitätsklinik, Hauptstrasse 5, D-79104 Freiburg i. Br., Germany.

Copyright (C) 1995 Society for Neuroscience 0270-6474/95/155800-10\$05.00/0
}

Microglia are the immunocompetent cells of the brain. Most likely, they derive from mononuclear cells of the blood but adopt special features in brain tissue. Extensive investigations on this cell type in recent years have revealed a variety of characteristics related to or distinct from blood monocytes (for reviews, see Giulian, 1987; Jordan and Thomas, 1988; Perry and Gordon, 1991). A special feature of microglia apparently is their expression of genes typical for cells of the lymphoid lineage, such as a lipopolysaccharide (LPS)-inducible $\mathrm{K}^{+}$channel (Nörenberg et al., 1993), or interleukin-3 (Gebicke-Haerter et al., 1994). Furthermore, it has been shown that these cells respond to a number of cytokines including granulocyte macrophage-colony stimulating factor (GM-CSF) and IL-3 with enhanced proliferation (Giulian and Ingeman, 1988; Ganter et al., 1992). The responsiveness to IL-3 suggests the concomitant expression of IL-3 receptors in microglia. These receptors belong to a larger family of cytokinc receptors (Bazan, 1990; 1991; Stahl and Yancopoulos, 1993; Sato and Miyajima, 1994), generally composed of two subunits ( $\alpha$ and $\beta$ ). The murine II -3 receptor $\beta$ - (Gorman et al., 1990; Itoh et al., 1990) and $\alpha$-subunits (Hara and Miyajima, 1992) have been cloned recently. The results revealed the presence of two $\beta$-subunits in this species. One subunit (clone AIC2A) appears to transduce only the IL-3 signal (Wang et al., 1992), whereas the other subunit (clone AIC2B) is required to transduce signals from IL-3-, IL-5, and GM-CSF (Takaki et al., 1991; Miyajima ct al., 1992a). This common subunit likely corresponds to the $\beta_{\mathrm{c}}$-subunit that has been identified in humans (Hayashida et al., 1990; Kitamura et al., 1991; Kitamura and Miyajima, 1992). AIC2B-derived gene product as well as the human $\beta_{\mathrm{c}}$-subunit do not bind the ligand (Wang et al., 1992). Typically, $\alpha$-subunits are responsible for (low-affinity) binding of the cytokines. Ligand-activated $\alpha$-subunits associate with $\beta$-subunit. This high-affinity form of the receptor transports the signal across the plasma membrane.

Hence, in mice, IL-3 is endowed with a dual signal transduction option through two homologous but distinct $\beta$-subunits. Until now, no information about two comparable subunits in the rat or any sequence data about the rat IL-3 receptor ( $\alpha$ - and $\beta$-subunits) have been available. The present study was aimed at gaining more insight into the molecular biology of the rat IL-3 receptor. Based on the cDNA sequence of the murine IL3-specific transducing unit (AIC2A), we sought to identify a homologous subunit in rat microglia by RT-PCR and to obtain its full-length cDNA sequence. The findings strongly suggest the lack of such a subunit and reveal the presence of only one common $\beta_{\mathrm{c}}$-subunit. Using part of the new cDNA as a rat-specific probe, we studied the question of whether or not this subunit is 
Table 1. Oligonucleotide primers used in this study

\begin{tabular}{|c|c|c|c|c|}
\hline & 5'-Primer & 3'-Primer & $\begin{array}{l}\text { Size of PCR } \\
\text { product }\end{array}$ & PCR conditions \\
\hline I & \multirow[t]{3}{*}{ 5'-AAGCGGCTTCAGGACTCC } & AGGTAGGGCCCATTGAAG-3' & $1253 \mathrm{bp}$ & 35 cycles $54^{\circ} \mathrm{C}$ \\
\hline II & & CGGGCCACATAGATACTGTT-3' & & \\
\hline III & & GACCCAGAGGTTGCAAGTGT-3' & $766 \mathrm{bp}$ & 35 cycles $62^{\circ} \mathrm{C}$ \\
\hline IV & 5'-CTGGCAGACCCAGGAAGCAA & CTGTGGTGATGCTCAGGCTC-3' & $1140 \mathrm{bp}$ & 30 cycles $58^{\circ} \mathrm{C}$ \\
\hline $\mathrm{V}$ & 5'-ATGGAGCCCAGAGGTACACT & TACTGGAGAAGGTCACCGTG-3' & 829 bp & 30 cycles $60^{\circ} \mathrm{C}$ \\
\hline VI & 5'-ACGTCAACACTGCTCTACA & CTTTGCCATAGTCCTTAAC-3' & $311 b p$ & 35 cycles $54^{\circ} \mathrm{C}$ \\
\hline
\end{tabular}

subject to LPS-mediated regulation in cultured microglia. Finally, we have chosen two pathological paradigms to investigate its gene induction and mRNA localization in vivo. These investigations clearly show a very rapid induction (within a few hours) of rIL-3R $\beta$ mRN $\Lambda$ in brain microglial cells. Strategies aimed at inhibiting induction of this receptor (e.g., anti-inflammatory therapies) might be suitable to better contain brain damage.

\section{Materials and Methods}

\section{Microglial cultures}

Floating microglial cells were harvested from confluent mixed astrocyte cultures and plated in new culture dishes. After adherence, media was removed and more culture supernatants from mixed astrocyte cultures were added to reach higher cell densities. Isolated cells were pure as tested previously by a varicty of ccll typc spccific markcrs (GcbickeHaerter et al., 1989). Lipopolysaccharide (S. typhimurium, SEBAK, Aidenbach, Germany)-treated and control cells were lysed in guanidinium isothiocyanate/mercaptoethanol solution, and total RNA was extracted according to Chomczynski and Sacchi (1987).

\section{$P C R$-based cloning and sequencing of the rat $I L-3$ receptor $\beta$-subunit}

Primer pair I (Table 1) was selected from the published murine sequence (Gorman et al., 1990) and used in reverse transcriptase-polymerase chain reaction (RT-PCR) with total microglial RNA. Multiple bands were obtained after electrophoretic separation of PCR mixture. A DNA band of approximately $1.2 \mathrm{~kb}$ size was excised from the gel and PCR amplified again. The resulting cDNA band was cloned into PCR (ix) II plasmid (Invitrogen, San Diego, CA) and sequenced on an automatic laser fluorescence sequencer (ALF). Sequence information of this cDNA fragment was used to select two inverse primers (II, III; Table 1) for the $5^{\prime}$ rapid amplification of cDNA ends (RACE) method (purchased from GIBCO-BRL, Eggenstein, Germany). The cDNA product was cloned and sequenced as above. To obtain the $3^{\prime}$ end, a new primler selected from the first rat sequence and an inverse complementary primer selected from a region downstream of the AIC2A stop codon and highly conserved between mouse and human (IV; Table 1) were used in RT-PCR (Fig. 1). All subsequent studies on gene regulation in the rat were carried out with an additional primer pair selected from the rat sequence (V; Table 1I). Specific PCR conditions are listed in Table 1.
For semiquantitative estimation of PCR products, $\mathrm{CDNA}^{\mathrm{s} 12}$ (a ribosomal protein) was amplified from the same RT mixtures using the primers listed in Table 1 (VI) (Ayane et al., 1989). It is assumed that this mRNA does not change significantly upon the treatments employed in this study, and that it allows for an estimation of the integrity of the RNA.

\section{Animal treatments}

Lipopolysaccharide (LPS) administration. Male Sprague-Dawley rats $(180-200 \mathrm{gm})$ were injected intravenously with $5 \mathrm{mg} / \mathrm{kg}$ LPS (E. coli, 055 B5 Westphal, Difco) dissolved in sterile saline (Buttini and Boddeke, 1994). Control animals received injections of $0.9 \%$ saline alone. At different times after LPS injections ( $1 \mathrm{hr}, 3 \mathrm{hr}, 6 \mathrm{hr}, 1 \mathrm{~d}, 2 \mathrm{~d}$ ), animals werc decply anesthetized by an intraperitoneal injection of $50 \mathrm{mg} / \mathrm{kg}$ pentobarbital and blood was removed through intracardial perfusion with sterile, heparinized PBS. Brains were removed, freed from meninges, and dissected on ice. Tissue from cortex, hippocampus, striatum, diencephalon, cerebellum, brainstem, and the pituitary gland was prepared, immediately homogenized in solution D (Chomezynski and Sacchi, 1987), snap frozen, and stored at $-70^{\circ} \mathrm{C}$ until processed for RNA extraction.

Middle cerebral artery occlusion (MCAO). Spontaneously hypertensive, male rats (SHR) weighing 250-300 gm were used. Under isoflurane anesthesia, the left middle cerebral artery (MCA) was permanently occluded with a bipolator, as described in detail elsewhere (Tamura et al., 1981; Sauter and Rudin, 1986). Sham-operated animals were treated in the same way, except for closing the MCA. SH rats were used, since MCAO induces a highly reproducible total infarct size in these rats that exceeds that of normal Wistar-Kyoto rats by $60 \%$. This allows a better assessment of histopathological changes (Sauter and Rudin, 1995).

At different times after MCAO (30 min, $1 \mathrm{hr}, 3 \mathrm{hr}, 6 \mathrm{hr}, 8 \mathrm{hr}, 1 \mathrm{~d}, 2$ $\mathrm{d}, 4 \mathrm{~d}$ ), rats were killed by decapitation, brains were quickly removed, and ischemic and nonischemic hemispheres were separated. Brainstem and cerebellum were discarded. Since blood of brain regions supplied by the MCA cannot be removed by intracardial perfusion after occlusion, MCA-occluded rats were not perfused. Brain tissue was homogenized in solution D (Chomczynski and Sacchi, 1987), snap frozen, and stored at $-70^{\circ} \mathrm{C}$ until further processing.

\section{In situ hybridization}

Brain tissue. LPS-treated and MCA-occluded rats were killed by decapitation, brains were quickly removed, and frozen on dry ice. Cryestat
Cloning strategy of the rat IL-3 receptor-B subunit

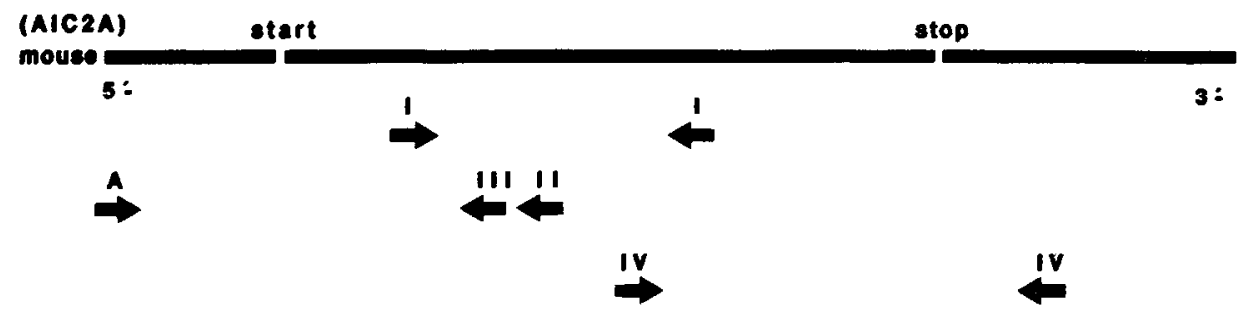

Figure 1. Schematic representation of PCR-based cloning strategy of interleukin-3 receptor- $\beta$ from rat microglial RNA. $I-I V$, Oligonucleotide primers used for RT-PCR as listed in Table 1. Primers I were selected from the murine AIC2A sequence. Primers II and III were derived from the new rat sequence and used for RACE. $A$ is the anchor primer supplied with the RACE kit. A stretch of $20 \mathrm{bp}$ of the nontranslated, $3^{\prime}$-flanking region, highly conserved between murine and human sequences was selected to construct reverse primer IV. 
Figure 2. Nucleotide sequence of rat interleukin-3 receptor- $\beta$ cDNA and changes in murine AIC2A receptor sequence. Putative signal sequence, transmembrane region, and ligand binding domain are overlined, or double overlined, respectively. WS X WS motif of cytokine receptor family is indicated in italics, and respective stop codons are marked $* * *$.

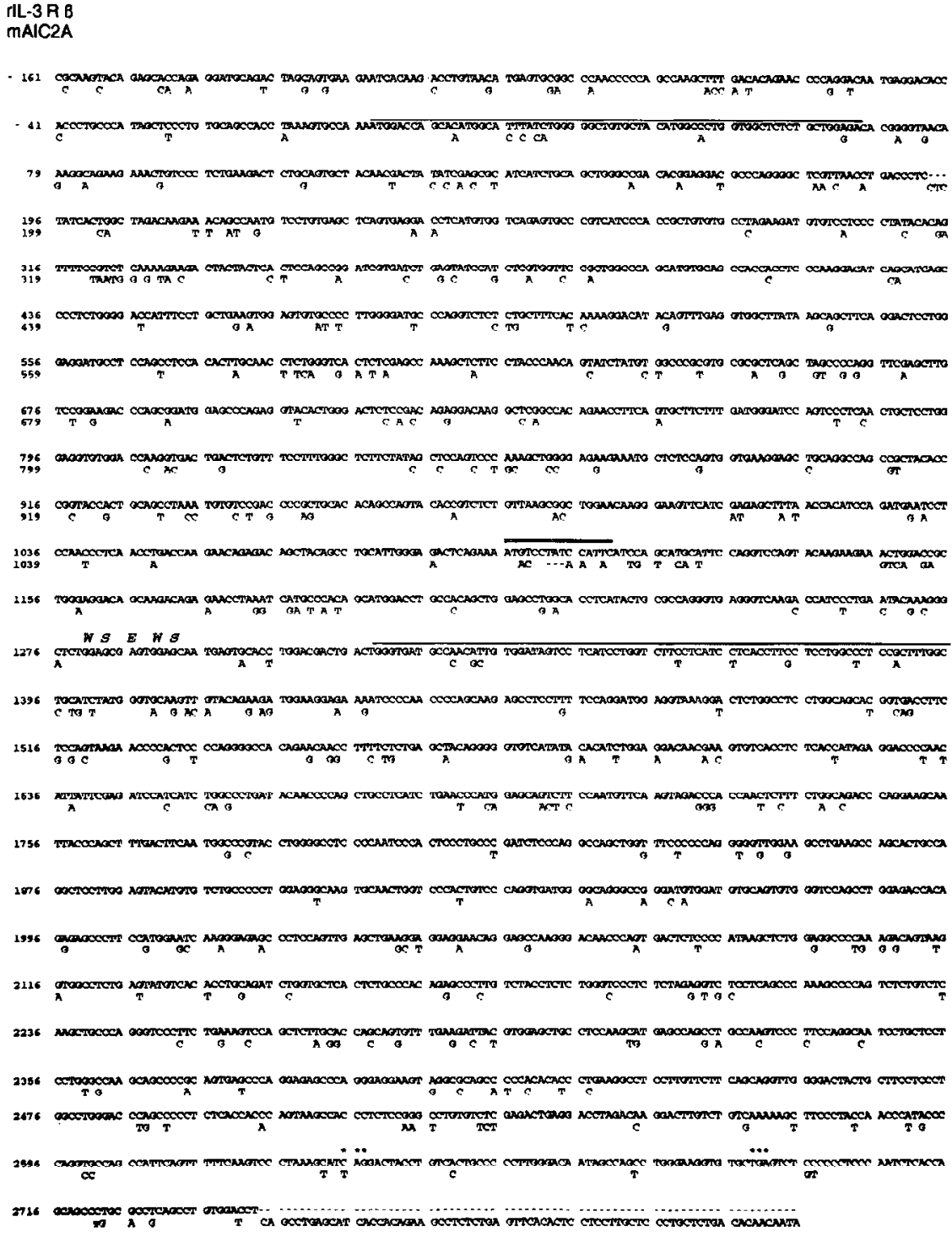

sections $(20 \mu \mathrm{m})$ were thaw mounted onto Vectabond-coated slides and stored at $-70^{\circ} \mathrm{C}$ until use. Sections were thawed, air dried, and fixed for $20 \mathrm{~min}$ by immersion in $4 \%$ paraformaldehyde in PBS (2.6 $\mathrm{mm}$ $\mathrm{KCl}, 1.4 \mathrm{mM} \mathrm{KH} \mathrm{PO}_{4}, 136 \mathrm{mM} \mathrm{NaCl}, 8 \mathrm{mM} \mathrm{Na}_{2} \mathrm{HPO}_{4}$, pH 7.4) at room temperature. Then they were washed once in $3 \times \mathrm{PBS}$, twice in $1 \times$ PBS, for $5 \mathrm{~min}$ each, and then incubated for $10 \mathrm{~min}$ in $0.1 \mathrm{M}$ triethanolamine, $\mathrm{pH} 8.0$, containing $0.25 \%$ acetic anhydride. After two washes in $1 \times$ PBS, 5 min each, sections were processed for nonradioactive in situ hybridization.

RNA probes and in vitro transcription. The pCR ${ }^{\text {II }}$ plasmid (INVITROGEN, San Diego, Ca.) with cloned fragment of rIL-3R $\beta$ (see above) was used to generate cRNA transcripts. Lincarization of plasmid with Not 1, followed by transcription with SP6 RNA polymerase (Boehringer, Mannheim, Germany), generates rIL-3R $\beta$ antisense riboprobe; linearization with $\mathrm{BamH} 1$ and transcription using T7 RNA polymerase generates the corresponding sense probe. Probes were digoxigenin (dig)-labeled using dig-labeled rUTP (400 $\mu \mathrm{M}$, Boehringer), $2 \mu \mathrm{g}$ linearized DNA template, $100 \mu \mathrm{M}$ dithiothreitol (DTT), 4 U RNase inhibitor, $40 \mathrm{~mm}$ Tris- $\mathrm{HCl}(\mathrm{pH} \mathrm{7.5),6} \mathrm{mm} \mathrm{MgCl}, 2 \mathrm{mM}$ spermidine, $5 \mathrm{~mm}$ $\mathrm{NaCl}, 1000-2000$ U DNA-dependent RNA polymerase. The transcription reaction was carried out for $45 \mathrm{~min}$ at $37^{\circ} \mathrm{C}$, then $1000 \mathrm{U}$ of the respective polymerase were added and the reaction mixture was incubated for additional $45 \mathrm{~min}$. The DNA template was degraded by addition of $2 \mathrm{U}$ DNase I and subsequent incubation at $37^{\circ} \mathrm{C}$ for $10 \mathrm{~min}$. DNase reaction was stopped by addition of $80 \mu \mathrm{l} 25 \mathrm{~mm}$ EDTA. Diglabcled probes werc purified on a Bio-Spin 30 column (Rio-Rad, Munich, Germany) according to the manufacturer's instructions. Before hy- bridization, labeled transcripts were ethanol precipitated, degraded to an average length of 150 base pair (bp) by partial alkaline hydrolysis (Cox et al., 1984), ethanol precipitated again, and resuspended in $80 \mu \mathrm{l}$ TE buffer (1 mM EDTA, $10 \mathrm{~mm}$ Tris- $\mathrm{HCl}, \mathrm{pH}$ 7.4) containing $0.1 \mathrm{M}$ DTT.

Hybridization and posthybridization treatment. Hybridization solutions were composed of dig-labeled transcripts (400-500 ng/ml 4× SSC hybridization buffer), $50 \%$ formamide, $10 \%$ dextran sulfate, $1 \times$ Denhardt's $(0.02 \%$ polyvinylpyrrolidone, $0.02 \%$ Ficoll, $0.02 \%$ bovine serum albumin, $250 \mu \mathrm{g} / \mathrm{ml}$ yeast tRNA, $400 \mu \mathrm{g} / \mathrm{ml}$ salmon sperm DNA, 500 $\mu \mathrm{g} / \mathrm{ml}$ heparin Na salt). Prehybridization was performed for $3 \mathrm{hr}$ at room temperaturc. For hybridization, each slide was overlaid with $70 \mu \mathrm{l}$ hybridization solution containing the appropriate amount of labeled transcript and incubated over night at $55^{\circ} \mathrm{C}$ in a chamber humidified with $4 \times$ SSC. After hybridization, sections were washed for $10 \mathrm{~min}$ in two changes of $2 \times \mathrm{SSC}$ at room temperature and $30 \mathrm{~min}$ in $0.1 \times \mathrm{SSC}$ at $70^{\circ} \mathrm{C}$. They were then treated with RNase A $(20 \mu \mathrm{g} / \mathrm{ml}$ in RNase buffer: $0.5 \mathrm{M} \mathrm{NaCl}, 1 \mathrm{~mm}$ EDTA, $10 \mathrm{~mm}$ Tris- $\mathrm{HCl}, \mathrm{pH} 7.4$ ) for $30 \mathrm{~min}$ at $37^{\circ} \mathrm{C}$. After a wash in RNase buffer for $30 \mathrm{~min}$ at room temperature, sections were subjected to two additional high-stringency washing steps in $0.1 \times$ SSC at $70^{\circ} \mathrm{C}, 40 \mathrm{~min}$ each. Then sections were rinsed in $2 \times \mathrm{SSC}$ and subjected to immunological detection as described below.

Immunological detection of dig-labeled hybrids. Slides were washed in $1 \times$ PBS for $10 \mathrm{~min}$ at room temperature. Nonspecific binding sites were blocked by incubation in PBS containing 3\% sheep serum and $0.3 \%$ Triton $\mathrm{X}-100$ for $45 \mathrm{~min}$ at room temperature. Slides were then incubated in the same buffer with 1:300 diluted alkaline phosphatase- 
conjugated anti-dig antibody for $2 \mathrm{hr}$ at $37^{\circ} \mathrm{C}$. After three washes in PBS, $10 \mathrm{~min}$ each, and incubation in TBS, pH 9.2, containing $50 \mathrm{~mm}$ $\mathrm{MgCl}_{2}$, for $5 \mathrm{~min}$, color was developed with $0.3 \mathrm{mg} / \mathrm{ml}$ nitroblue tetrazolium (NBT) and $0.1 \mathrm{mg} / \mathrm{ml}$ 5-bromo-4-chloro-3-indolyl phosphate (BCIP) in the same buffer containing $0.24 \mathrm{mg} / \mathrm{ml}$ levamisole for 14-16 $\mathrm{h}$ at room temperature. Color reaction was stopped by transfer of slides into PBS. Sections were then covered with Crystal-Mount medium (Biomedia), dried for $20 \mathrm{~min}$ at $50^{\circ} \mathrm{C}$, and coverslipped with Depex (Merck, Darmstadt, Germany).

\section{Results}

$P C R$-based cloning of the rat $I L-3$ receptor $\beta$-subunit ( $r I L$ 3Rß) from isolated microglia

Specific primers devised on the basis of the murine master sequence (AIC2A; Hara and Miyajima, 1992) were successfully used in RT-PCR amplifications of respective rat sequences (Table 1, primer pair I). Identity of PCR products was verified by cloning of the PCR product into $\mathrm{PCR}^{\mathrm{TM}} \mathrm{II}$ plasmid and subsequent sequencing of the insert. The new rat sequence was used to select and synthesize two appropriate reverse primers for the 5'-RACE method (Frohman et al., 1988). The PCR product was processed as described above. The 3 '-end of rat IL-3 receptor- $\beta$ was identified as described in Methods and Materials. Figure 1 summarizes the cloning strategy, and Figure 2 shows the complete cDNA sequence of rIL-3R $\beta$ in comparison with murine AIC2A sequence.

\section{Primary structure of cloned rat IL-3 receptor $\beta$-subunit (rIL- 3R $\beta$ )}

The new rat cDNA sequence encodes a polypeptide of 896 amino acid residues. It shows a single base pair exchange at the location of the murine (AIC2A) stop codon (TAG into CAG), which results in an elongation of the translated cDNA by 54 base pairs (Fig. 2). The stop codon in the rat sequence is located at a site corresponding to the stop site in the murine AIC2B. Despite sequencing a number of different clones and additional direct sequencing of the PCR product, the location of the stop codon was unchangcd.

In Figure 3, amino acid sequences of murine AIC2A and AIC2B are compared to the rat sequence predicted from the new cDNA sequence. The rat sequence has $77.7 \%$ and $79.5 \%$ amino acid sequence identity with murine $\mathrm{AIC} 2 \mathrm{~A}$ and $\mathrm{AIC} 2 \mathrm{~B}$, respectively. The $\mathrm{N}$-terminal 22 amino acid residues constitute a hydrophobic amino acid sequence typical of signal peptides (Klein et al., 1985). The WSXWS notif typical for cytokine receptors (Miyajima et al., 1992b) preceding the membrane spanning region (double overlined) is put in italics. It is identical with the murine AIC2A, but differs from murine AIC2B. Another WSXWS-like motif is located beginning with amino acid 229 (PSXWS). Furthermore, the external domain contains eight conserved cysteine residues $(39,49,77,94$, and $253,263,292,309)$. Four potential N-glycosylation sites are found in positions 62 , 262,312 , and 349 , the first and last being conserved between murine and human sequences. One site critical for ligand binding (Wang et al., 1992) is printed in bold. In contrast to the murine sequences, it shows an insertion of one amino acid and resembles more AIC2B than AIC2A. According to the mutagenesis results by Wang et al. (1992) performed in mice, rIL$3 R \beta$ likely is not suitable for specific ligand binding. Apart from 151 species-specific amino acid exchanges (exchanges in second and third lines), there are amino acids in the rat either identical with AIC2A (exchanges only in third line) or AIC2B (exchanges only in second line). Thirty-two amino acids or deletions are identical with $\mathrm{AIC} 2 \mathrm{~A}$, and 31 are identical with AIC2B. Alto- gether, these data suggest that in the rat there is only one IL-3 receptor $\beta$-subunit comparable to the $\beta_{c}$-subunit in humans.

\section{Occurrence of $r I L-3 R \beta$ mRNA in microglial cultures}

To investigate rIL-3R $\beta$ mRNA expression in culture, isolated microglia were maintained up to 1 week in the absence or presence of LPS $(100 \mathrm{ng} / \mathrm{ml})$. Results in Figure 4 clearly show that the receptor was expressed in LPS-free conditions, and culture time had no significant influence on transcriptional rate. It is important to note that the number of PCR cycles had to be reduced to 28 when using RNA preparations from cultured cells. LPS substantially increased transcription of rIL-3R $\beta$ mRNA beginning between 0 and $4 \mathrm{hr}$ of LPS treatment. Elevated receptor mRNA was invariably found even after 1 week of LPS treatment. S12 mRNA, used as internal standard, was unchanged in all conditions (Fig. 4, bottom).

\section{Occurrence of $r I L-3 R \beta m R N A$ in rat brain and its regulation by $L P S$}

A variety of brain areas were investigated before and after systemic administration of LPS. In untreated animals, rIL-3R $\beta$ mRNA was undetectable by RT-PCR. Three hours after injection of LPS, however, mRNA was found in all brain regions investigated (Fig. 5). The highest amounts were observed in cerebellum, diencephalon, cortex, and hippocampus. Maximum expression was attained between $6-10 \mathrm{hr}$ of LPS treatment. After 24 $\mathrm{hr}, \mathrm{mRNA}$ levels had declined to baseline in most regions except in cerebellum and dicncephalon. S12 cDNA amplificd from cach respective RT mixture served as control for an equal quality of RNA and comparable reverse transcriptions (bottom panel). In situ hybridizations with a receptor-specific antisense probe revealed occurrence of rIL-3R $\beta$ mRNA throughout the brain as early as $3 \mathrm{hr}$ after LPS injection. The scattered appearance (Fig. 6A) and morphologies of receptor-positive cells (Fig. 6B,C) were strongly reminiscent of microglia. No signal was obtained in parallel in situ hybridizations with sense probes (not shown).

\section{$r I L-3 R \beta$ mRNA expression after occlusion of the middle cerebral artery (MCAO)}

Receptor mRNA was traceable by RT-PCR $1 \mathrm{hr}$ after artery occlusion in the affected brain hemisphere and reached peak values between 8 and 24 hr. A significant decline was observed at day 2 after occlusion, and there was barely any rIL-3R $\beta$ mRNA detectable by RT-PCR at day 4 (Fig. 7). In situ hybridizations revealed scattered $\mathrm{rIL}-3 \mathrm{R} \beta \mathrm{mRNA}$-positive cells at 3 $6 \mathrm{hr}$ after onset of ischemia in brain regions originally supplied by the middle cerebral artery (frontal, fronto-parietal, and temporal cortex, caudate putamen, globus pallidus, part of hippocampus, lateral thalamus, and amygdala; not shown). One day after MCAO, increasing numbers of rIL-3R $\beta$ mRNA-positive cells were observed in the infarcted brain areas as well as in parenchyma adjacent to infarct region. Additionally, morphologies of cells changed with time. Two days after MCAO, many cells in infarct core showed condensed morphologies with no or short stout extensions (Fig. $8 B, E, F$ ). Supposedly, it is a mixture of blood macrophages and brain microglia. In more remote areas of the affected hemisphere, positive cells displayed more ramified morphologies (Fig. $8 A, C, D$ ) suggestive of microglial cells in different states of activation. No positive cells were observed in hybridizations with sense probes (not shown). 
Figure 3. Amino acid (AA) sequence deduced from rat IL-3 receptor- $\beta$ cDNA in comparison to murine $\mathrm{A}$ and B subunits (AIC2A and AIC2B). Signal and transmembrane regions are single or double overlined, characteristic cytokine receptor motif is in italics, and putative ligand binding domain is in bold. Apart from species-specific differences (AA changes in second and third lines), 31 AA were identical with AIC2B (AA changes only in second line), and $32 \mathrm{AA}$ were identical with AIC2A.
TIL- 3RB
MAIC2A

MAIC2B

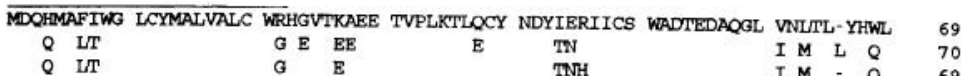

DKKQPMSCEL SEDLMWSECP SSHRCVPRRC VLPYTQFSVS KEDYYSLQPD RDLSIHLVVP LAQHVQPPPP 139

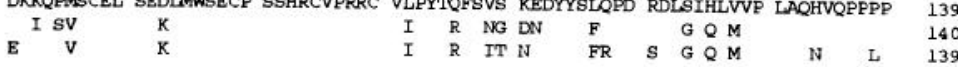

KDISISPSGD HFLLKWSVPL GDAQVSLUSQ KDIQFEVAYK QLODSWEDAS SLHTCNLWVT LEPKLFLPNS 209

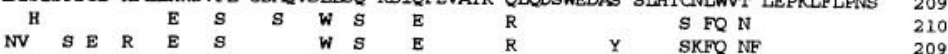

IYVARVRAQL APGSSLSGRP SGWSPEVHWD SPTEDKARPQ NLQCFFDGIQ SLNCSWEVWT KVTDSVSFGL 279

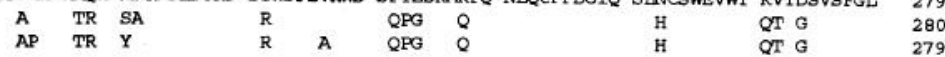

FYSSSPKAGE KKCSPVVKEL Q-ASRYTRYH CSLNVSDPAA HSQYTVSVKR LEQGKFIESF NHIOMNPPTT RP A P B $\begin{array}{llllllllllll}\text { RP } & \text { A P } & \text { E } & \text { P } & \text { V } & \text { R } & \text { P PE S } & \text { H } & \text { M Y Y } & \text { E } & \text { I } & 349 \\ \text { RP } & \text { V P } & \text { E } & \text { P PG } & \text { V } & & \text { P PE S } & \text { H } & \text { M Y } & \text { E } & & 349\end{array}$

NLTKNRDSYS LHWETOKOLSYPFIQHAFQVQ YKKKLDRWED SKTENLNHAH SMDLPQLEPG TSYCARVRVK

TIPEYKGLMSEWGNECTWTT DWVMPTLWIV LILVFLILTF LLALRFGCIY GCKLYRRWTE KIPNPSKSLL 488

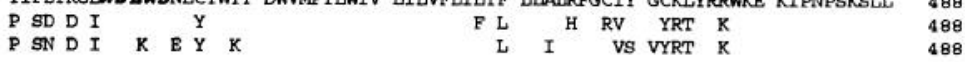

FODGGKGLWP PGSTVTFSSK NPTPQGPQNN LFSELQGVSY THLEDNEVSP LIIIEDPNIIR DPSSGPDTTP 558 $\begin{array}{llllllll}\text { MAA AT } & \text { AL } & \text { SR } & \text { LA Q } & \text { E } & \text { N } & \text { P R } & 558\end{array}$

AASSEPMEOS SNVQVDPPTL SGRPRKOLPS FDFNGPYLGP POSHSLPDLP GQLVSPOGVG SLKPALPGSL

ST L P EG IP $S$ P G VG

628 628

EYMCLPPGG VQLVPLSQVM GQGRDVVVC GSSLETTESP SMESRESPPV ELKEEEQEPR DNPVTLPISS $\begin{array}{llllllll} & \text { QAM } & \text { G } & \text { V PK N } & \text { SV K A } & \text { M } & 698 \\ \text { A } & \text { QAM } & \text { SG } & \text { V PK N } & \text { SM A } & & 698\end{array}$

GGPKDSKVAS EYVTPADLVL TLPTEPLSTS LGPSLEVSSA QSPSLCLKLP RVPSESPALA PAVFEDYVEL 768 $\begin{array}{lllllllll}B G M M & D & G P & G & \text { GLP } & \text { G } & \text { G } & \text { PG } & 768 \\ B G M & \text { D } & \text { G P } & G & \text { GLP } & \text { G } & \text { G } & \text { PG } & 768\end{array}$

PPEMEQPAKS LPGNPAPPGP SSPAVSPGEP REEVGAPTY PEGLLVLQQV GDYCFLPGLG PSPLSPPSKP 83

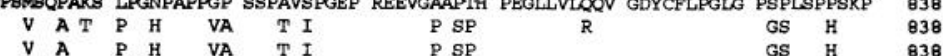

PSPGLCLETE DLDKDLSVKK LPYQPIPQVP AIQFFKSLKH QDYLSLPPWD NSQPGKVC`

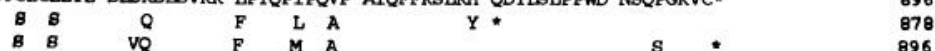

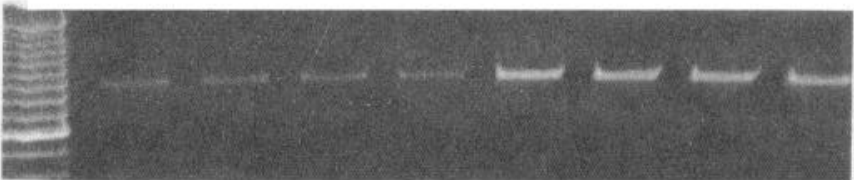

rIL-3r B

marker $4 \mathrm{~h} 12 \mathrm{~h} 24 \mathrm{~h} 1 \mathrm{wk} 4 \mathrm{~h} 12 \mathrm{~h} 24 \mathrm{~h} \mathrm{1wk}$

Figure 4. IL-3 receptor- $\beta$ expression in cultured rat microglia. Time-course study in absence (left four lanes) or presence of LPS $(100 \mathrm{ng} / \mathrm{ml})$. LPS increased receptor mRNA invariably stayed at elevated level up to 1 week. No significant quantitative changes were observed in LPS-free microglia during 1 week, either. For comparison, S12 cDNA is shown below. Marker, 100 bp ladder (GIBCO BRL).
- L P S
+ L P S

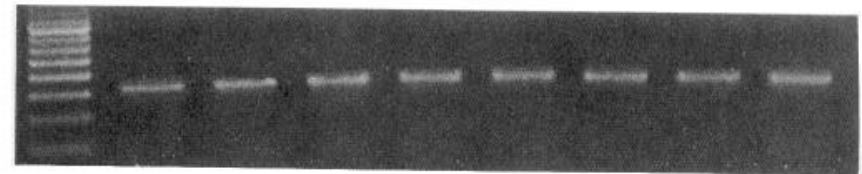


$0 h$

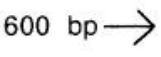

$3 h$

$6 \mathrm{~h}$

$24 h$
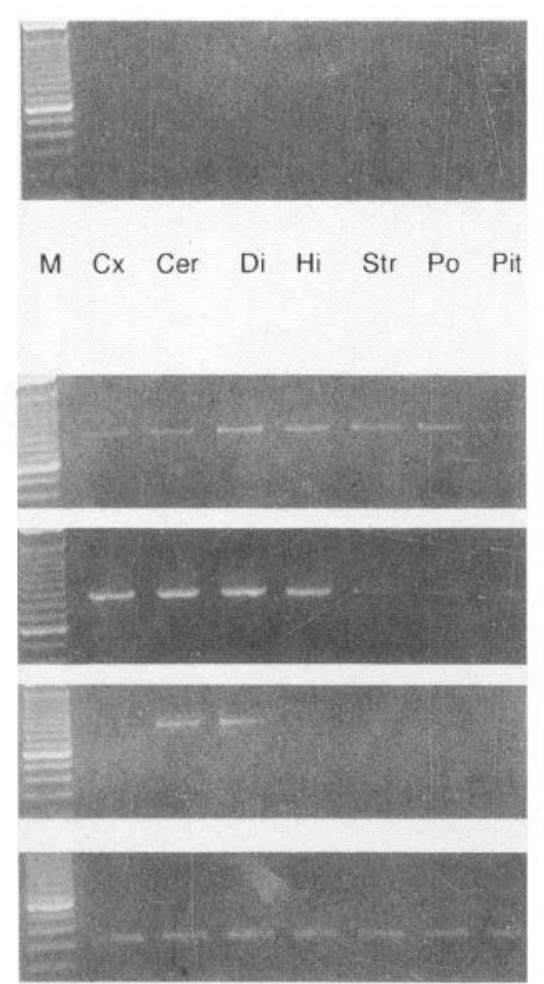

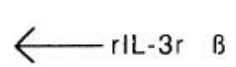

Figure 5. IL-3 receptor- $\beta$ induction in rat brain upon LPS-induced fever. Substantial amounts of receptor mRNA were detectable by RT-PCR $3 \mathrm{hr}$ after peripheral injection of LPS in cortex $(\mathrm{Cx})$, cerebellum $(\mathrm{Cer})$, diencephalon (Di), hippocampus $(H i)$, striatum (Str), pons $(\mathrm{Po})$, and pituitary $(\mathrm{Pit})$. Maximal receptor induction occurred at approximately $6 \mathrm{hr}$ and declined to undetectable levels in most brain regions $24 \mathrm{hr}$ after LPS injection. S12 cDNA was used as internal standard to make sure equal quantities of cDNAs were amplified. $M, 100$ bp DNA ladder.

\section{Discussion}

Receptor cloning

The cloned rIL-3R $\beta$ shares all the structural features known from related cytokine receptors including four conserved cysteine residues in its external domain and the unique WSXWS motif in close proximity to the transmembrane region. No kinase domain is found in the cytoplasmic region of the sequence. Moreover, the new sequence reveals a number of features interesting in both evolutionary and biochemical aspects. Apart from species-specific differences, there are almost $50 \%$ amino acid exchanges in $\mathrm{AIC} 2 \mathrm{~A}$, where $\mathrm{AIC} 2 \mathrm{~B}$ and the rat sequences are identical, and $50 \%$ amino acid exchanges in AIC2B, where $\mathrm{AIC} 2 \mathrm{~A}$ and the rat sequences are identical. This finding strongly supports the likelihood of a developmental segregation of this gene between mouse and rat resulting in the lack of mRNA for a second $\beta$-receptor subunit in the rat. It was hypothesized previously, that closely related $\mathrm{AIC} 2 \mathrm{~A}$ and $\mathrm{AIC} 2 \mathrm{~B}$ genes were generated by gene duplication of a common ancestral gene (Hara and Miyajima, 1992), which raised the question why in humans (and now in rat) there is only one common $\beta$-subunit. The authors speculate, that $\beta_{c}$ may be the prototype gene, and gene duplication has occurred after divergence between the mouse and humans. On the other hand, neither we nor others (Hayashida et al., 1990) can exclude the possibility of the presence of a second $\beta$-subunit both in rats or humans, since the expression of AIC2A mRNA in mice can be very low (Gorman et al., 1990). If a homologous mRNA in the rat or man is expressed at comparable or even lower level, it may escape analytical techniques.

Provided there is only one (common) $\beta$-subunit expressed in the rat, one would anticipate cross-competition between GMCSF, IL-5, and IL-3, which does not occur in murine tissues between IL-3 and the other cytokines (Kitamura et al., 1991),

and which may impact on cellular responsiveness. Furthermore, the $3^{\prime}$-elongated form of the transducing unit in the rat may influence subsequent intracellular signalling pathways in ways distinct from the murine system, although in humans, major sites for signalling appear to reside in closer proximity to the plasma membrane (Sakamaki et al., 1992).

\section{LPS-induced rIL-3R $\mathrm{mRNA}$ expression in cultured microglia and in vivo}

The IL-3/IL-3 receptor system appears to become increasingly more interesting in brain research. The ligand reportedly has a beneficial effect for the survival of cholinergic neurons both in vitro and in vivo (Kamegai et al., 1990). Moreover, rIL-3R $\beta$ appears to be involved in certain pathological events, as shown here. Undoubtedly, the primary cell type expressing these genes is the microglial cell. We have shown recently (Appel et al., 1995), that IL-3 gene transcription can be upregulated by a variety of agents in cultured microglia, including LPS. The present data document that LPS also upregulates rIL-3R $\beta$ mRNA in the cultured cells. We also have preliminary data (Appel et al., in preparation) that IL-3 mRNA, after systemic injection of LPS, is induced within approximately $3 \mathrm{hr}$ in rat brain. The present results document that within the same time frame, IL-3 receptor- $\beta$ mRNA is induced in microglia in situ. The short time frame of induction and superfusion of brain precludes a confusion with blood-derived mononuclear cells. Hence, there is a good agreement of data obtained in culture with data obtained in vivo. The receptor subunit, however, was not downregulated in cultured microglia, suggesting the lack of feedback mechanisms in the purified cell population. In vivo, LPS may be degraded more efficiently, or may induce additional factors in other brain cell types that counterbalance the LPS effect. It is presently unclear to what extent LPS ( $5 \mathrm{mg} / \mathrm{kg}$ body weight) is able to 
Figure 6. Visualization of IL-3 receptor- $\beta$ mRNA-positive cells in brain of LPS-treated rats $(6 \mathrm{hr}$ after peripheral administration of $5 \mathrm{mg} / \mathrm{kg}$ LPS) using a dig-labeled receptor-specific cRNA. $A$, Low magnification of receptor-positive cells in cortex. $B$ and $C$, Higher magnification of receptor-positive cells. Note that ramified morphology of cells is reminiscent of microglia. No hybridization signal was obtained with sense probes (not shown). Scale bars: $14 \mu \mathrm{m}$ $(A), 8 \mu \mathrm{m}(B$ and $C)$.
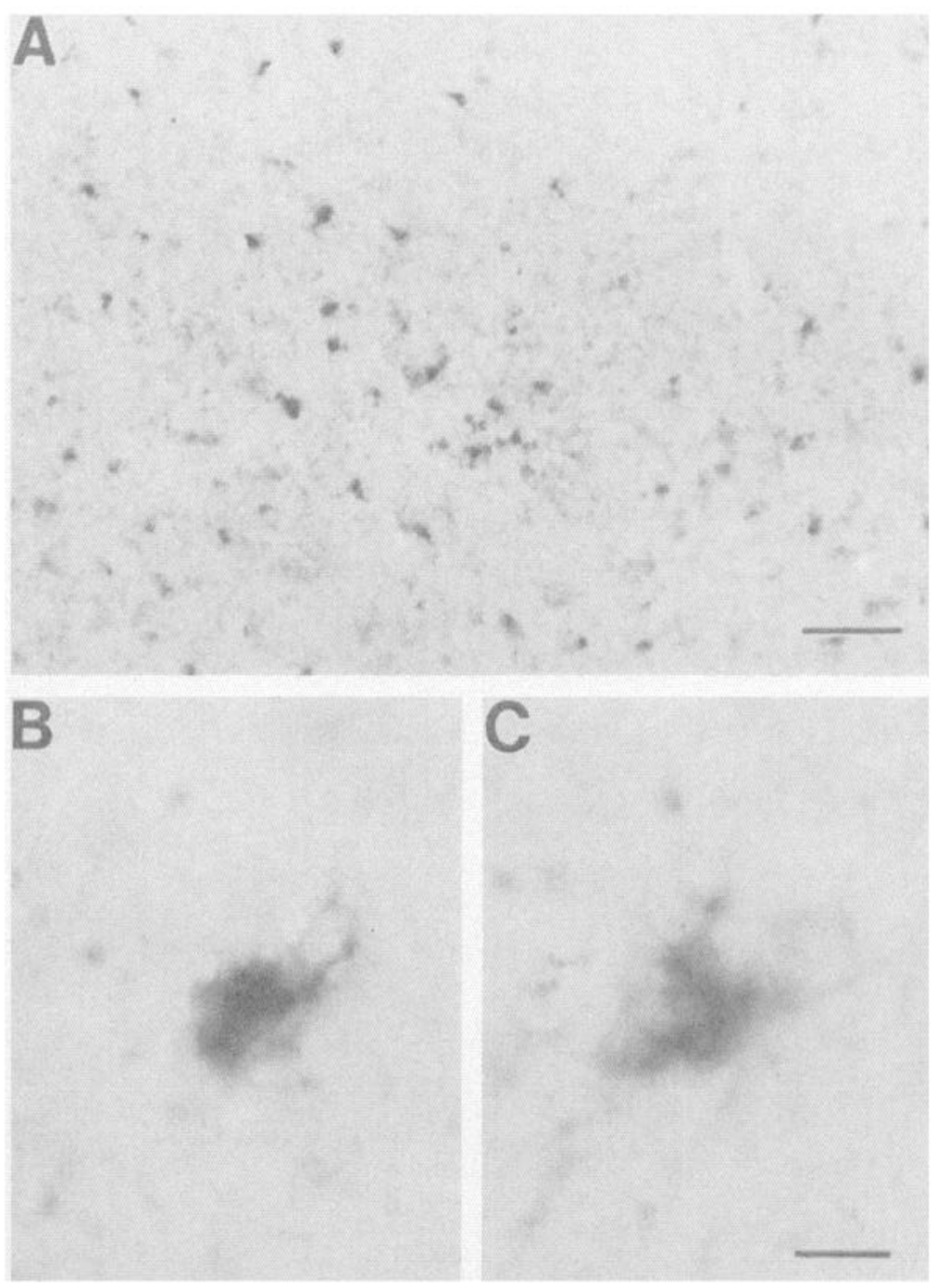

cross the blood-brain barrier, if at all. Additional experiments performed in our laboratory with lower LPS concentrations (1 $\mathrm{mg} / \mathrm{kg}$ body weight) also resulted in significant but much less pronounced microglial activations (Buttini et al., in preparation). Furthermore, investigations on endothelial cultures revealed enhanced permeability of plasma membranes in the presence of
LPS (Tunkel et al., 1991). These data point to a disturbance of the blood-brain barrier permeability caused by LPS. This might allow direct access of some LPS from the circulation to the brain parenchyma proper. The results could, however, also be interpreted as indicative of a transduction mechanism relaying the LPS signal across the blood-brain barrier. It is also a matter of
Figure 7. IL-3 receptor- $\beta$ mRNA induction in infarcted region of rat brain after occlusion of middle cerebral artery (MCAO). Receptor mRNA was already traceable by RT-PCR $3 \mathrm{hr}$ after surgery and reached maximum between 8 and $24 \mathrm{hr}$. A marked decline was observed $2 \mathrm{~d}$ after occlusion. RTPCR amplification using S12-specific primers is shown below.

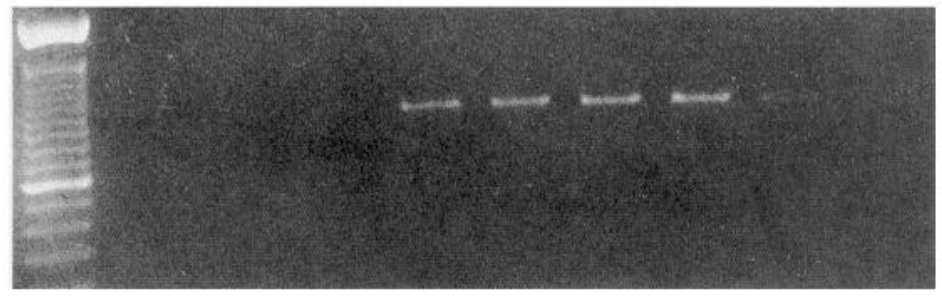

rIL-3r B

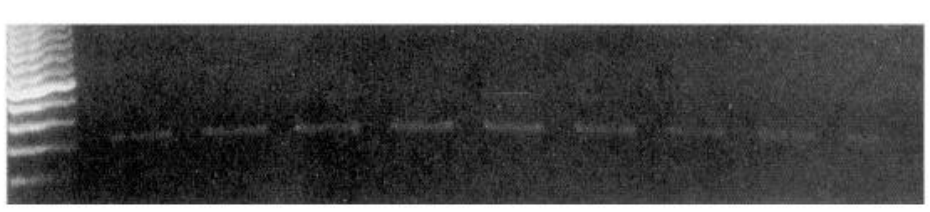



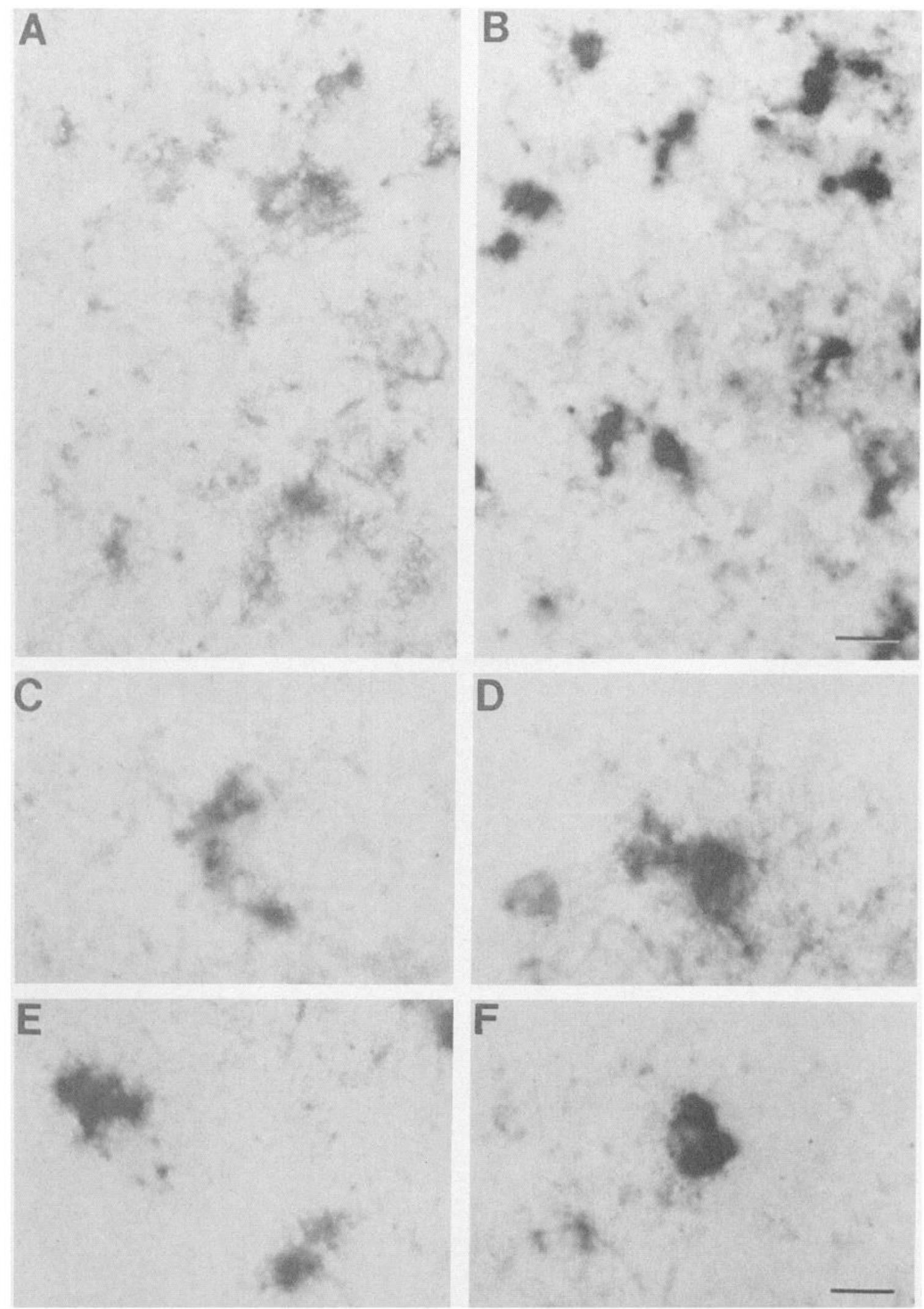

Figure 8. Visualization of IL-3 receptor- $\beta$ mRNA-positive cells in brain of MCAO rats ( $2 \mathrm{~d}$ after onset of ischemia) using a dig-labeled receptorspecific cRNA. $A$, rIL-3R $\beta$ mRNA-positive cells in brain tissue adjacent to infarct region. $B$, rIL-3R $\beta$ mRNA-positive cells in infarcted area. Note that receptor-positive cells in $A$ show morphology of partially activated microglia, whereas positive cells in $B$ display morphology of fully activated microglia with retracted, stout processes or are round-shaped cells reminiscent of reactive microglia or macrophages. $C-F$, Higher magnification of different activation states of receptor-positive microglia/macrophages. $C$ and $D$ are receptor-positive cells in tissue adjacent to infarct area; $E$ and $F$ are cells in infarct zone. No hybridization signal was obtained with sense probes (not shown). Scale bars: $14 \mu \mathrm{m}, 8 \mu \mathrm{m}$, respectively. 
speculation why IL-3 and rIL-3R $\beta$ are induced under fever conditions and in what way these transient gene expressions affect microglial cell numbers and functions of other brain cells. Moreover, it seems reasonable to assume, that the rIL-3R $\alpha$-subunit is also expressed upon LPS application. Experiments are under way to resolve this question. At any rate, the presence of IL-3 under pathological conditions suggests that rIL-3R $\beta$ is used as transducer for the IL-3 signal. GM-CSF or IL-5, if induced, may also use this pathway (Takaki et al., 1991; Vairo and Hamilton, 1991; Duronio et al., 1992). Although GM-CSF and IL-5 appear to be inducible by LPS in cultured murine astrocytes resp. microglia (Sawada et al., 1993; Mizuno et al., 1994), no data are available as concerns the occurrence of both cytokines under MCAO conditions.

\section{Induction of rIL-3R $\beta$ by occlusion of the middle cerebral artery $(M C A O)$}

Evidently, rIL-3R $\beta$ mRNA is not only induced in microglia upon LPS administration. MCAO-dependent lesioning also elicits (molecular or ionic) signals stimulating rIL-3R $\beta$ gene transcription. Although identification of these factors warrants further investigations, the involvement of LPS in this paradigm is highly unlikely. For instance, the time course of rIL-3R $\beta$ induction is significantly slower and longer lasting than in the fever model. In another paradigm of ischemia, microglial activation was investigated up to $7 \mathrm{~d}$ after occlusion by a number of immunocytochemical markers (Gehrmann et al., 1992). Those results show an onset of microglial reactions somewhere between 0 and $24 \mathrm{hr}$ after surgery, and strongest stainings of some markers occurred only after $7 \mathrm{~d}$. Whether or not this indicates a more delayed time course of microglial activation remains to be determined. In these cases, rIL-3R $\beta$ induction may, indeed, result in a marked increase of microglial cell numbers. It would be of great clinical interest to know what kind of anti-inflammatory measures are suitable to specifically inhibit rIL-3R $\beta$ expression and subsequent expansion of immunocompetent cells in the injured tissue. Since rIL-3R $\beta$ expression is a very early event of microglia activation, its inhibition would be a means of interference near the beginning of unwanted cell or tissue destruction.

Due to the type of surgery, perfusion prior to brain removal was omitted. Therefore, and because no microglia-specific markers are available, it was not possible to discern blood-borne monocytes from resident brain microglia in core or areas immediately adjacent to the infarct. Although data are available, that murine mast cell lines and macrophage cell lines express AIC2B mRNA (Gorman et al., 1990), it would be interesting to know whether or not blood monocytes from rat can also express rIL-3R $\beta$.

In summary, appearance of rIL-3R $\beta$ (and ligand) mRNA within a few hours after a pathological stimulus demands a very fast transcriptional activation of these genes in brain microglia. The present results lead us to conclude that $\mathrm{rL}-3 \mathrm{R} \beta$ plays a crucial role in early events of microglial activation in vivo.

\section{References}

Appel K, Honegger P, Gebicke-Haerter, PJ (1995) Expression of interleukin- 3 and tumor necrosis factor- $\beta$ mRNAs in cultured microglia. $\mathrm{J}$ Neuroimmunol, in press.

Ayane M, Nielsen P, Köhler G (1989) Cloning and sequencing of mouse ribosomal protein S12 cDNA. Nucleic Acid Res 17:6722.

Bazan JF (1990) Structural design and molecular evolution of a cytokine receptor superfamily. Proc Natl Acad Sci USA 87:6934-6938.
Bazan JF (1991) Neuropoietic cytokines in the hematopoietic fold. Neuron 7:197-208.

Buttini M, Boddeke HWGM (1994) Peripheral lipopolysaccharide stimulation induces IL- $1 \beta$ messenger RNA in rat brain microglial cells. Neuroscience 65:523-530.

Chomczynski P, Sacchi N (1987) Single step method of RNA isolation by acid guanidinium thiocyanate-phenol-chloroform extraction. Anal Biochem 162:156-159.

Cox KH, DeLeon DV, Angerer LM, Angerer A (1984) Detection of mRNAs in sea urchin embryos by in situ hybridization using asymmetric RNA probes. Dev Biol 101:485-502.

Duronio V, Clark-Lewis I, Federsppiel B, Wieler JS, Schrader JW (1992) Tyrosine phosphorylation of receptor $\beta$ subunits and common substrates in response to interleukin-3 and granulocyte-macrophage colony-stimulating factor. J Biol Chem 267:21856-21863.

Frohman MA, Dush MK, Martin GR (1988) Rapid production of fulllength cDNAs from rare transcripts: amplification using a single gene-specific oligonucleotide primer. Proc Natl Acad Sci USA 85: 8998-9002

Ganter S, Northoff H, Männel D, Gebicke-Haerter PJ (1992) Growth control of cultured microglia. J Neurosci Res 33:218-230.

Gebicke-Haerter PJ, Bauer J, Schobert A, Northoff H (1989) Lipopolysaccharide-free conditions in primary astrocyte cultures allow growth and isolation of microglial cells. J Neurosci 9:183-194.

Gebicke-Haerter PJ, Appel K, Taylor GD, Schobert A, Rich IN, Northoff H, Berger M (1994) Rat microglial interleukin-3. J Neuroimmunol 50:203-214.

Gehrmann J, Bonnekoh P, Miyazawa T, Hossmann K-A, Kreutzberg GW (1992) Immunocytochemical study of an early microglial activation in ischemia. J Cereb Blood Flow Metab 12:257-269.

Giulian D (1987) Ameboid microglia as effectors of inflammation in the central nervous system. J Neurosci Res 18:155-171.

Giulian D, Ingeman JE (1988) Colony-stimulating factors as promoters of ameboid microglia. J Neurosci 8:4707-4717.

Gorman DM, Itoh N, Kitamura T, Schreurs J, Yonehara S, Yahara I, Arai K-I, Miyajima A (1990) Cloning and expression of a gene encoding an interleukin 3 receptor-like protein: identification of another member of the cytokine receptor gene family. Proc Natl Acad Sci USA 87:5459-5463.

Hara T, Miyajima A (1992) Two distinct functional high affinity receptors for mouse interleukin-3 (IL-3). EMBO J l l:1875-1884

Hayashida K, Kitamura T, Gorman DM, Arai K-I, Yokota T, Miyajima A (1990) Molecular cloning of a second subunit of the receptor for human granulocyte-macrophage colony-stimulating factor (GMCSF): reconstitution of a high-affinity GM-CSF receptor. Proc Natl Acad Sci USA 87:9655-9659.

Itoh N, Yonehara S, Schreurs J, Gorman DM, Maruyama K, Ishii A, Yahara I, Arai K-I, Miyajima A (1990) Cloning of an interleukin-3 receptor gene: a member of a distinct receptor gene family. Science 247:324-327.

Jordan FL, Thomas WE (1988) Brain macrophages: questions of origin and interrelationship. Brain Res Rev 13:165-178.

Kamegai M, Niijima K, Kunishita T, Nishizawa M, Ogawa M, Araki M, Ueki A, Konishi Y, Tabira T (1990) Interleukin 3 as a trophic factor for central cholinergic neurons in vitro and in vivo. Neuron $2: 429-436$.

Kitamura T, Miyajima A (1992) Functional reconstitution of the human interleukin-3 receptor. Blood 80:84-90.

Kitamura T, Sato N, Arai K-I, Miyajima A (1991) Expression cloning of the human IL-3 receptor CDNA reveals a shared $\beta$ subunit for the human IL-3 and GM-CSF receptors. Cell 66:1165-1174.

Klein P, Kanehisha M, Delisi C (1985) The detection and classification of membrane spaning proteins. Biochem Biophys Acta 815:468476.

Miyajima A, Hara T, Kitamura T (1992a) Common subunits of cytokine receptors and the functional redundancy of cytokines. Trends Biochem Sci 17:378-382.

Miyajima A, Kitamura T, Harada N, Yokota T, Arai K-I (1992b) Cytokine receptors and signal transduction. Annu Rev Immunol 10:295331.

Mizuno T, Sawada M, Suzumura A, Marunouchi T (1994) Expression of cytokines during glial differentiation. Brain Res 656:141-146.

Nörenberg W, Appel K, Bauer J, Gebicke-Haerter PJ, Illes P (1993) Expression of an outwardly rectifying $\mathrm{K}^{+}$channel in rat microglia cultivated on teflon. Neurosci Lett 160:69-72. 
Perry VH, Gordon S (1991) Macrophages and the nervous system. Int Rev Cytol 125:203-244.

Sakamaki K, Miyajima I, Kitamura T, Miyajima A (1992) Critical cytoplasmic domains of the common $\beta$ subunit of the human GM-CSF, IL-3 and IL-5 receptors for growth signal transduction and tyrosine phosphorylation. EMBO J 11:3541-3549.

Sato N, Miyajima A (1994) Multimeric cytokine receptors: common versus specific functions. Curr Opin Cell Biol 6:174-179.

Sauter A, Rudin M (1986) Calcium antagonists reduce extent of infarction in rat middle cerebral artery occlusion model as determined by quantitative magnetic resonance imaging. Stroke 17:1228-1234.

Sauter A, Rudin M (1995) Strain-dependent drug effects in rat middle cerebral artery occlusion model of stroke. J Pharm Exp Ther, in press.

Sawada M, Suzumura A, Marunouchi T (1993) Production of interleukin- 5 by mouse astrocytes and microglia in culture. Neurosci Lett 155:175-178.

Stahl N, Yancopoulos GD (1993) The alphas, betas, and kinases of cytokine receptor complexes. Cell 74:587-590.
Takaki S, Mita S, Kitamura T, Yonehara S, Yamaguchi N, Tominaga A, Miyajima A, Takatsu K (1991) Identification of the second subunit of the murine interleukin-5 receptor: interleukin-3 receptor-like protein, AIC2B is a component of the high affinity interleukin- 5 receptor. EMBO J 10:2833-2838.

Tamura A, Graham DI, McCulloch J, Teasdale GM (1981) Focal cerebral ischaemia in the rat: 1 . Description of technique and early neuropathological consequences following middle cerebral artery occlusion. J Cereb Blood Flow Metab 1(1):53-60.

Tunkel AR, Rossen SW, Hansen EJ, Scheld WM (1991) Blood-brain barrier alterations in bacterial meningitis: development of an in vitro model and observations on the effects of lipopolysaccharide. In Vitro Cell Dev Biol 27a:113-120.

Vairo G, Hamilton JA (1991) Signalling through CSF receptors. Immunol Today 12:362-369.

Wang H-M, Ogorochi T, Arai K-I, Miyajima A (1992) Structurc of mouse interleukin 3 (IL-3) binding protein (AIC2A). Amino acid residues critical for IL-3 binding. J Biol Chem 267:979-983. 